\title{
SURFACE MOVEMENT, HYDROLOGICAL CHANGE AND EQUILIBRIUM FLOW ON LEMON CREEK GLACIER, ALASKA
}

\author{
By Calvin J. Heusser \\ (American Geographical Society, New York, U.S.A.) \\ and Melvin G. Marcus \\ (Department of Geography, Rutgers University, New Brunswick, New Jersey, U.S.A.)
}

\begin{abstract}
Lemon Creek Glacier served as the focus of attention of the Juneau Ice Field Research Project from 1953 through 1958. During the International Geophysical Year, it represented one of the glaciological stations in the North American network. This paper presents some of the results of these studies, its purposes being ( 1 ) to discuss the $1953-58$ annual hydrological budgets, and (2) to test Nielsen's equations for the equilibrium glacier using 1957 and 1958 movement and hydrological data.

It is found that each budget year for the period studied shows a deficit, except $1954-55$ which registered a pronounced surplus. The net deficit amounts to $10.32 \times 10^{6} \mathrm{~m} .{ }^{3}$ of water. The $1956-57$ budget was only slightly negative $\left(0.82 \times \mathrm{IO}^{6} \mathrm{~m} .{ }^{3}\right)$ but that for $1957-58$ was strongly negative $\left(8.96 \times \mathrm{IO}^{6} \mathrm{~m} .^{3}\right)$. Surface flow measurements were made along five transverse profiles, two of which were plotted over one full year. It is believed that the one-year measurements provide a more accurate and realistic picture of glacier flow than is normally available from short summer surveys. The glacier appears to be close to equilibrium and to behave in the manner predicted by Nielsen's theory of equilibrium flow.
\end{abstract}

RÉsumé. Le Lemon Creek Glacier a été le centre d'intérêt du Juneau Ice Field Research Project de 1953 à r $95^{8}$. Durant l'Année Géophysique Internationale, il représentait une des stations glaciologiques du réseau nord-américain. Cet article présente quelques résultats de ces études, ses buts étant: $1^{\circ}$ ) de discuter les budgets hydrologiques annuels de 1953 à $195^{8} ; 2^{\circ}$ ) de tester les équations de Nielsen pour un glacier en équilibre en utilisant les données de l'hydrologie et du mouvement de 1957 et 1958 .

Nous avons trouvé que chaque budget annuel pour la période étudiée montre un déficit, à l'exception de l'année 1954-55, durant laquelle on a enregistré un surplus prononcé. Le déficit net s'élève à $10,32 \times 10^{6} \mathrm{~m}^{3}$ d'eau. Le budget de $1956-57$ était légèrement négatif $\left(0,82 \times 10^{6} \mathrm{~m}^{3}\right)$, mais celui de $1957-58$ était fortement négatif $\left(8,96 \times 10^{6} \mathrm{~m}^{3}\right)$. Des mesures de l'écoulement en surface ont été faites le long de 5 profils transversaux parmi lesquels 2 ont été réalisés au-delà d'une année complète. On pense que les mesures annuelles donnent une image plus précise et plus réaliste de l'écoulement du glacier que celles provenant de courtes campagnes d'été. Le glacier semble être près de l'équilibre et se comporter de la façon prévue par la théorie de Nielsen sur l'écoulement en équilibre.

Zusammenfassung. Beim Juneau Ice Field-Forschungsunternehmen 1953-58 stand der Lemon Creek Glacier im Mittelpunkt des Interesses. Während des Int. Geophysikalischen Jahres war er eine der glaziologischen Stationen im Beobachtungsnetz Nordamerikas. Die vorliegende Arbeit enthält einige Frgebnisse dieser Untersuchungen, deren Zweck es war, ( I) den hydrologischen Jahreshaushalt von $1953^{-5} 5^{8} \mathrm{zu}$ ermitteln und (2) die Gültigkeit von Nielsen's Gleichungen für einen Gletscher im Gleichgewicht mit Hilfe der Bewegungen und hydrologischen Daten von 1957 und 1958 zu überprüfen.

Für jedes Haushaltsjahr der Beobachtungsperiode ergibt sich ein Defizit, - mit Ausnahme von I954-55 wo ein erheblicher Überschuss auftrat. Das Netto-Defizit beträgt $10,32 \times 10^{6} \mathrm{~m}^{3}$ Wasser. Der Haushalt $1956-57$ war nur schwach negativ $\left(0,82 \times 10^{6} \mathrm{~m}^{3}\right)$, aber $1957^{-58}$ trat ein starker Verlust auf $\left(8,96 \times 10^{6} \mathrm{~m}^{3}\right)$. In 5 Querprofilen wurden Fliessbewegungen an der Oberfläche gemessen; in zwei davon erstreckten sich die Messungen über ein volles Jahr. Es wird angenommen, dass die Jahresmessungen ein genaueres und zutreffenderes Bild der Gletscherbewegung vermitteln als es gewöhnlich aus kurzen Sommerbeobachtungen gewonnen werden kann. Der Gletscher scheint annähernd im Gleichgewicht zu sein und sich gemäss Nielsen's Theorie für die Gleichgewichtsbewegung zu verhalten.

\section{INTRODUCTION}

Comprehensive glaciological studies in the source regions of glaciers located in the Pacific coastal cordillera of north-western North America were begun in 1948. Project Snow Cornice was undertaken at that time by the Arctic Institute of North America in the SewardMalaspina sector of the St. Elias Mountains (Sharp, I949). In 1949, after a reconnaissance expedition the previous year, the American Geographical Society's Juneau Ice Field Research Project began observations on Taku Glacier in the northern Coast Mountains (Field and Miller, I950). The work of the Project on Lemon Creek Glacier began in r 953. Observations which had been focused on Taku Glacier from 1949 to I $95^{2}$ were suspended after I 953 except for photographic surveys. This changeover was the result of a recommendation by Dr. 
Hans W :son Ahlmann, who visited the Juneau Ice Field in 1952. Lemon Creek Glacier had been selected as representative of north-western North America in a scheme to observe glacier variations in different parts of the world and to "explain the reactions of glaciers to meteorological factors" (Ahlmann, 1953). It had also become evident after five expeditions that the extensive Taku Glacier, which is complex and necessitates having large field parties

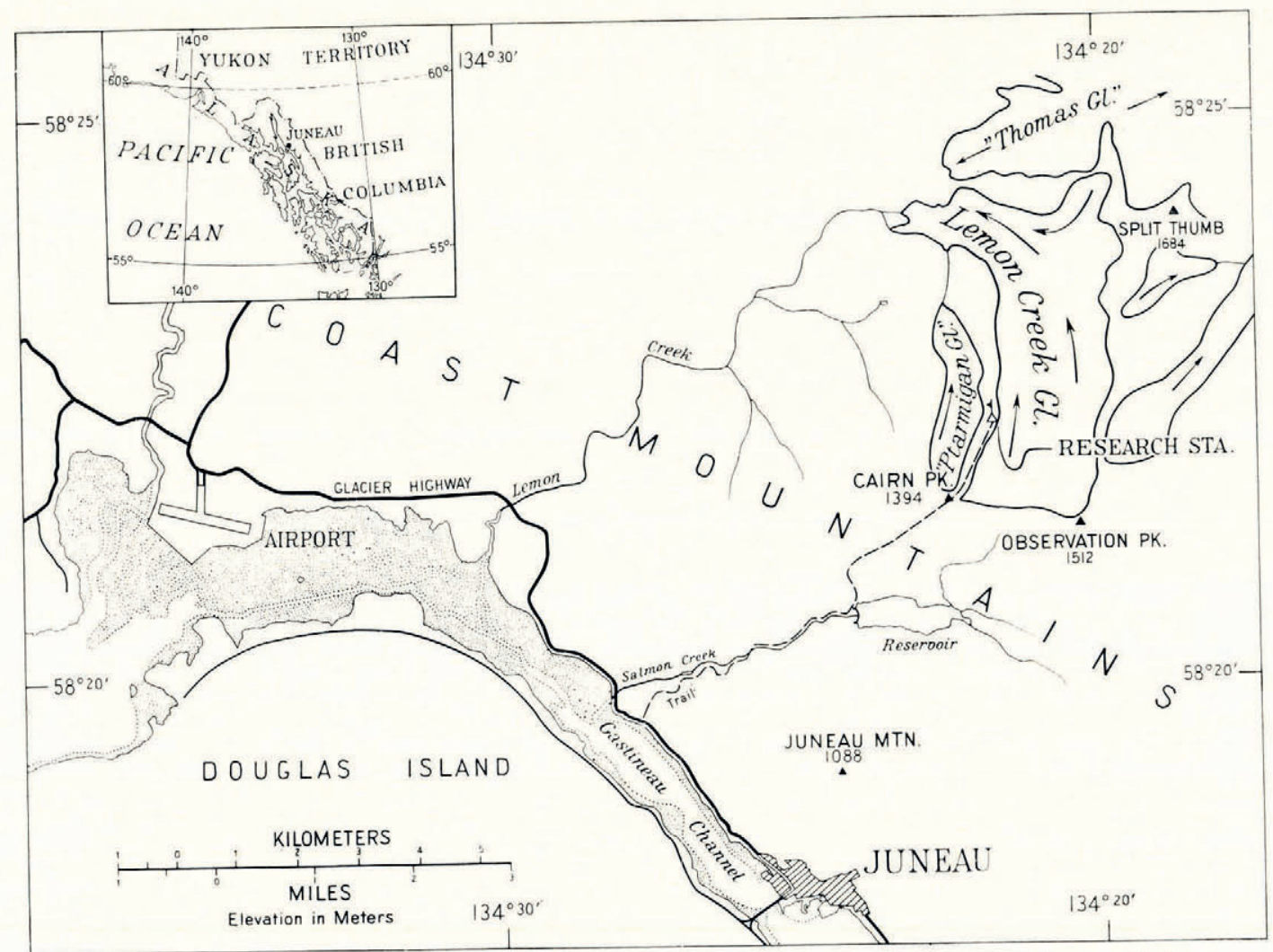

Fig. I. Sketch map showing the location of Lemon Creek Glacier and the surrounding area near Juneau, Alaska

and complicated logistics, was not well suited for long-term study. Lemon Creek Glacier, by contrast, covers a relatively small area, is not complex, and can be studied in detail by small parties.

Results of research executed on Lemon Creek Glacier from 1953 to the close of the project in $195^{8}$ have been summarized periodically in a series of general reports (American Geographical Society, r $953^{-58}$ ). Detailed studies have appeared in the literature from time to time. Hubley $(1955$, i 957) reported on the micrometeorological program which was concerned with energy transfer at the snow surface and included an evaluation of snow albedo. Thiel and others (1957) ascertained by a gravimetric method the thickness of the ice and were able to construct several cross-sections of the glacier. Wilson (1959), in turn, used these data along with data on surface movement and the average annual hydrological budget to test equations Nielsen (1955) had derived for the theory of equilibrium glaciers. According to the theory the budget is correlated with the transfer of ice through cross-sections as expressed by surface movement. Wilson was able to indicate close agreement between the ice mass annually ablated below the firn limit and the ice mass moving through the firn limit cross-section over 
the same period. Lemon Creek Glacier accordingly appeared to be close to an equilibrium condition.

This paper is intended to consolidate and interpret some of the data collected on the glacier between 1953 and $195^{8}$, placing particular emphasis on the $195^{8}$ field season. Its purposes are (I) to discuss the I $953-58$ annual hydrological budgets, and (2) to test further, using the additional r 958 movement and hydrological data, Nielsen's equations for the equilibrium glacier.

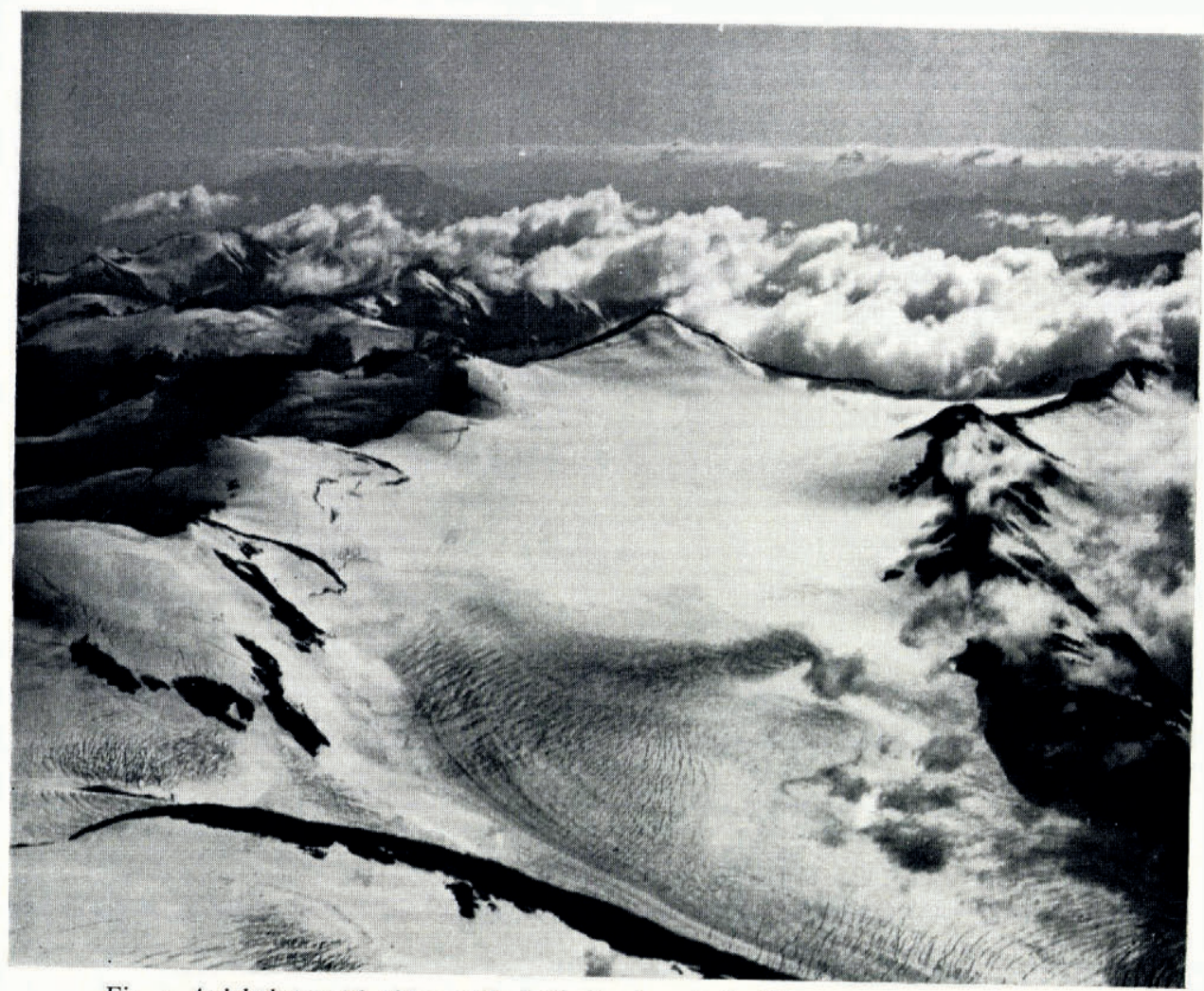

Fig. 2. Aerial photograph of Lemon Creek Glacier above the ice fall taken on 15 Septemoer 1957

\section{Lemon Creek Glacier: Location and Description}

Lemon Creek Glacier is a relatively small valley glacier located in the Coast Mountains of south-eastern Alaska about $6.5 \mathrm{~km}$. north-east of Juneau (Figs. I and 2). It forms the southernmost extension of the Juneau Ice Field and would be a separate entity were it not for narrow tenuous connections that make it technically part of the field. The Juneau Ice Field, lying east of lower Lynn Canal, is the southern part of an extensive glacier complex which straddles the crest of the Coast Mountains between the vicinity of Skagway and the Taku River valley, a distance of roughly $\mathrm{I} 45 \mathrm{~km}$.

Lemon Creek Glacier is unbranched and is oriented generally in a northerly direction, except near its snout where it curves westerly. The length of its longitudinal axis is $6 \cdot 4 \mathrm{~km}$. and its greatest width is close to $2 \mathrm{~km}$. Flow begins on the north-west slope of Observation Peak $(\mathrm{I}, 5 \mathrm{I} 2 \mathrm{~m}$.) and travels via an ice fall between elevations of 650 and $850 \mathrm{~m}$. to the terminus at $470 \mathrm{~m}$. Almost all flow follows this general course. The remainder drains southward from a 
divide at an elevation of approximately $\mathrm{I}, 225 \mathrm{~m}$. along the longitudinal axis and very near the glacier's head but does not descend lower in elevation than $\mathrm{I}, 200 \mathrm{~m}$.

A series of three broad steps distinguishes the profile of the glacier above the ice fall. Crevasses, narrowly opened for the most part, are on the surface in general profusion and appear in swarms where the descent of the ice is slightly steeper from one step to the next. The most uniform, least crevassed ice is found below the ice fall. The ice fall, by contrast, exhibits markedly broken ice where huge blocks have separated. This part of the glacier has

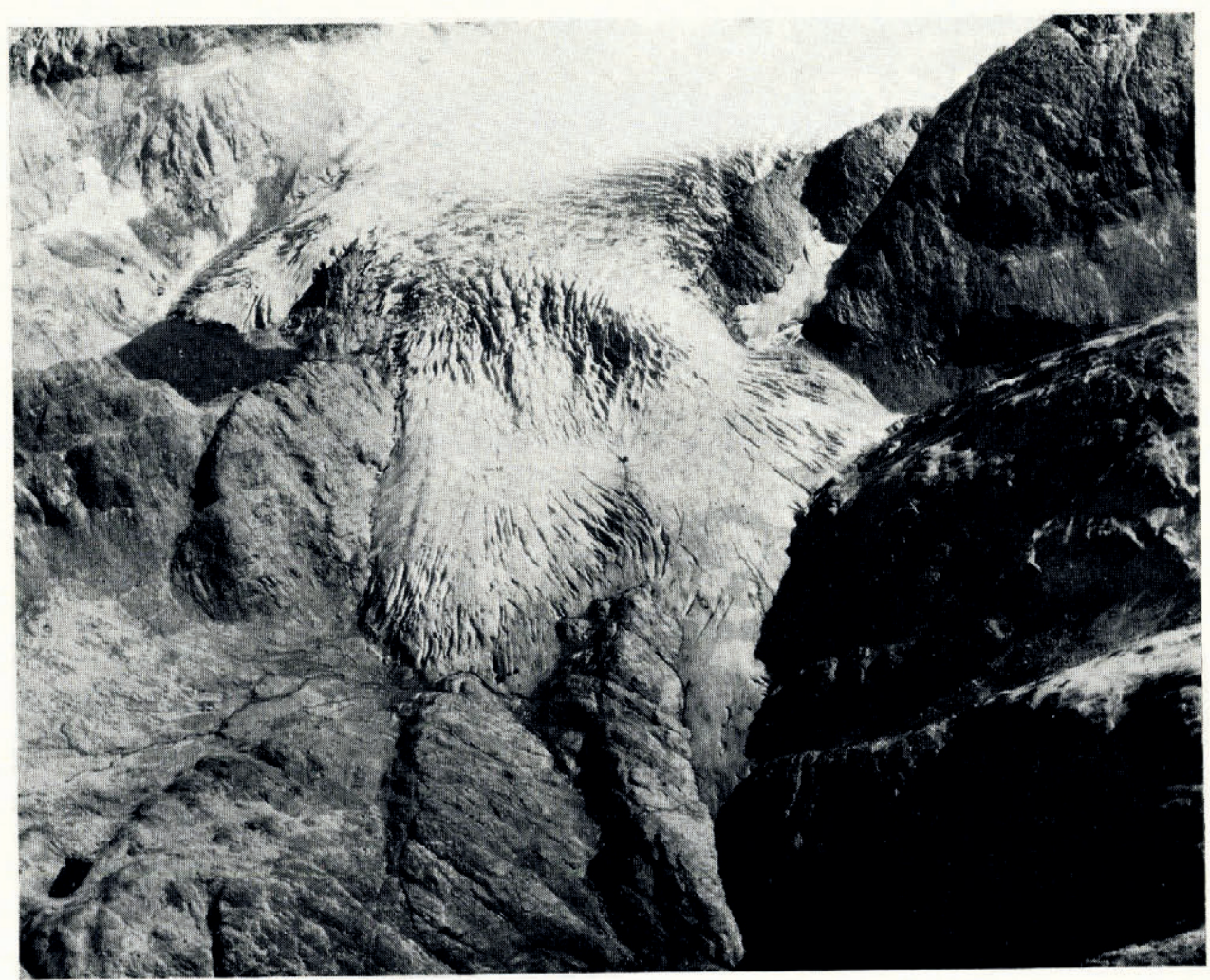

Fig. 3. Aerial photograph of Lemon Creek Glacier below the ice fall taken on 1o September 1958. (By courtesy of Dave Bohn)

the steepest slope, measuring $18 \cdot 5$ degrees. Below the ice fall the slope is 14.5 degrees; above, between the fall and the drainage divide near the head, it is only approximately 4 degrees. Thiel and others (1957) state that the maximum ice thickness found by gravimetry is just over $200 \mathrm{~m}$. and occurs in the upper central reaches. The maximum thickness about $\mathrm{I} \mathrm{km}$. above the ice fall is at least $150 \mathrm{~m}$. The glacier slope in the area of greatest thickness is 3.5 degrees; directly above the ice fall, it is $6 \cdot 3$ degrees. The slope of the underlying rock floor in these respective areas is $2 \cdot 4$ and 4.6 degrees.

The snout of the glacier is split by a rock cleaver so that the north portion is broad and lobate, whereas the south portion is pointed and arrow-shaped (Fig. 3). North-east of the snout and less than $\mathrm{r} \mathrm{km}$. up-glacier, a part of the ice terminates in a lake at an elevation of $709 \mathrm{~m}$. This lake, which is not evident on a 1946 aerial photograph can be seen beginning to form on photographs taken in $194^{8}$. 
The seasonal snow line on the glacier at the close of the ablation period between 1953 and I 958 varied between $c .875$ and $c$. I,200 $\mathrm{m}$. in elevation. In 1955 it was lowest in elevation and in 1958 highest. The total area of the Lemon Creek Glacier system determined by planimetry is $12.67 \times 10^{6} \mathrm{~m}^{2}$. This figure is the sum of the small area which drains southward $\left(0.62 \times 10^{6} \mathrm{~m} .{ }^{2}\right)$, an area feeding from the north-eastern sector but contributing negligible quantities of ice $\left(2.69 \times \mathrm{ro}^{6} \mathrm{~m}^{2}\right)$ and the main northerly draining area which is used in budget determinations for $195^{6}-57$ and $1957^{-58}\left(9 \cdot 36 \times 10^{6} \mathrm{~m}^{2}\right)$. These areas are delineated in Figure 4 .

\section{Hydrological Budget}

The hydrological budget of a glacier is based on the annual amounts of ice ablation and net snow accumulation. Loss or gain, in terms of equivalent water volume, is calculated for a budget year which opens when late summer or early autumn snow accumulation exceeds the ablation of ice at the firn limit and which continues through to the close of the ablation period the following year when accumulation is again in excess.

It is apparent that the opening and close of each budget year does not take place on any single day. These times are transitional and may be several weeks in duration. When the ablation period is ending, for example, snow accumulation in excess of ice ablation at the firn limit may not occur without interruption until mid-autumn, and as a result, ice ablation during this interval can be important. LaChapelle (American Geographical Society, r955) computed during the 1954-55 budget year on Lemon Creek Glacier that, of the total ice melted, as much as 15.6 per cent was lost during the first two weeks of September. Because of the importance of late-season ablation, a budget calculation that does not take this entire transitional interval into account will suffer inaccuracy. Ablation data for budget calculations on Lemon Creek Glacier should span the months of June through September in order to cover the ablation period.

Inaccuracies in budget studies arise for other reasons. These errors are recognized but precise measurements are required to modify them. They include the following: (I) snow compaction causing the amount of ablation at a stake to appear to be greater than that which has actually taken place; (2) ablation measurements providing inadequate coverage of the ablation zone whereby certain topographic influences are overlooked; (3) net accumulation surveys being based on few probes and neglecting steeper, less accessible areas of the upper glacier; (4) no allowance being made in calculations of the ablation area for firn whose density is less than ice and whose inclusion in the budget causes ablation volumes to be smaller, and (5) assuming a constant rate for the progression of the snow line up-glacier, especially when positions of the snow line on widely spaced dates are used in calculations.

\section{International Geophysical Year budgets $1956-58$}

Ablation-accumulation surveys were run in the field seasons of 1957 and $195^{8}$ when Lemon Creek Glacier served as one of the glaciological stations in the North American network during the International Geophysical Year. In 1957 a map of the glacier was plotted at the Institute of Geodesy, Photogrammetry and Cartography at The Ohio State University under the American Geographical Society I.G.Y. program 4. I I (Case, I958). The map, prepared from aerial photography by the U.S. Navy on 18 September 1957 and ground control established by the project in 1955 , is drawn at a scale of $\mathrm{I}: \mathrm{I}$, ooo with contour intervals of $5 \mathrm{~m}$. (American Geographical Society, 1960). It is the basis for the area measurements employed in the budget computations for $195^{6-57}$ and $1957^{-5}$, shown below. The total area of the glacier taken into account in the budgets for these years is delimited in Figure 4 and amounts to $9.36 \times \mathrm{IO}^{6} \mathrm{~m}^{2}$.

Wilson (1959) reported on the $195^{6-57}$ budget studies, but at the time he prepared his report, the map of the glacier drawn in 1957 was not available. He computed a deficit of 


\section{LEMON CREEK GLACIER}

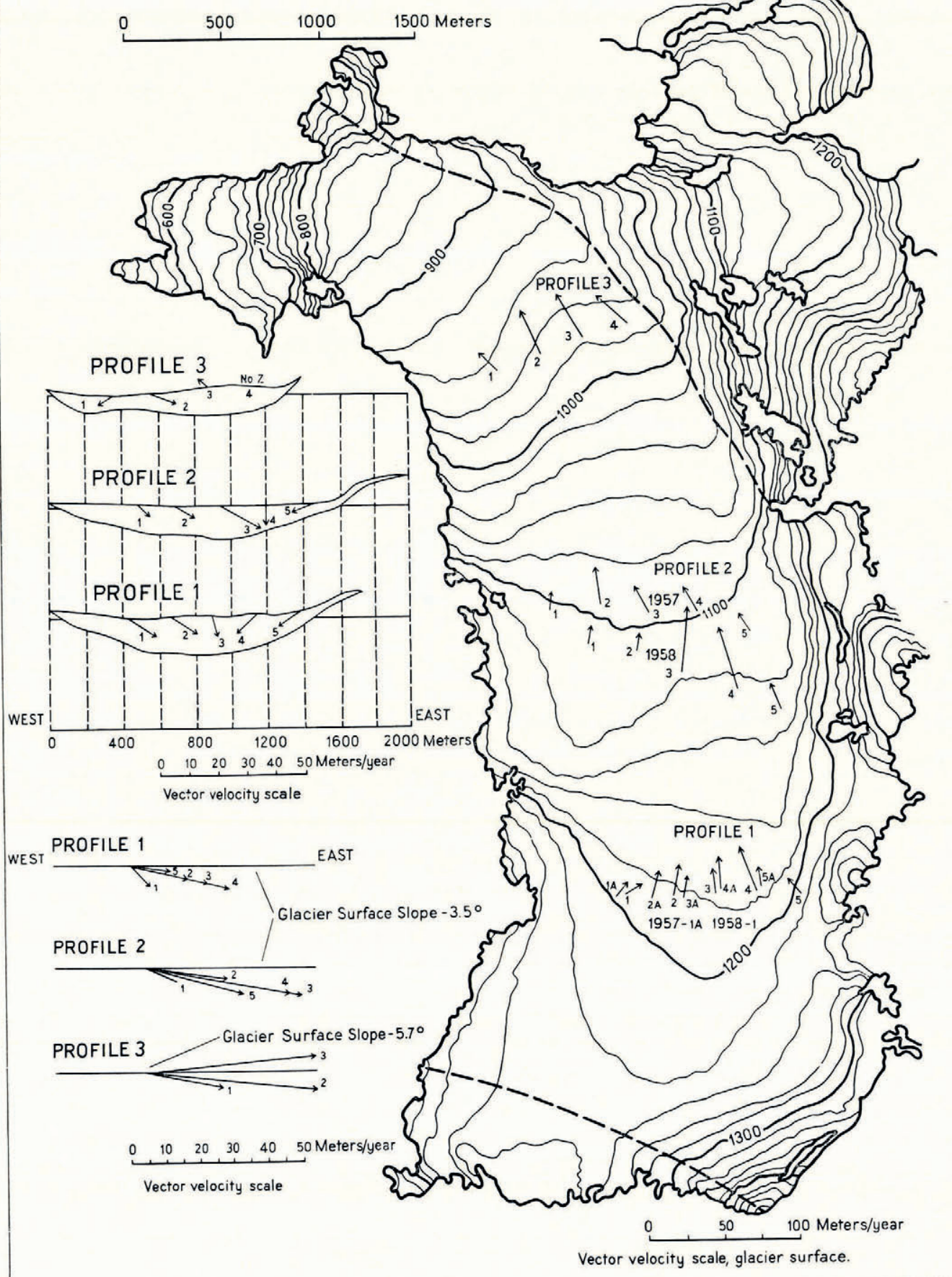

Fig. 4. Contour map and cross-sections of Lemon Creek Glacier showing vector velocities and directions of movement stakes 
$4.0 \times 10^{6} \mathrm{~m} .{ }^{3}$ of water. This figure is revised below using new values for the areas of the ablation and accumulation zones in conjunction with Wilson's data for vertical ablation and accumulation. The procedure used to calculate the budget was as follows:

Field parties established a network of ablation measurement sites as early in the ablation season as possible. Holes in the ice were drilled using a $2.5 \mathrm{~cm}$. ice drill. Since most of the ice ablation surface is normally under a cover of snow at this time, it was necessary to drill through the cover before implanting the measurement stakes. In both 1957 and 1958, personnel were occupied on other glaciers during much of the summer, but observations were made on Lemon Creek Glacier early and late in the ablation season. It was thus possible to measure total summer ablation at each of the stake locations. These provided, of course, only a sample of the total ablation surface and did not take into account those areas up-glacier and downglacier from the ablation profiles. Since the snow line does not necessarily progress up-glacier at a constant rate, the amount of ice ablating between successive positions of the snow line also had to be considered. This was accomplished by determining the average rate of ablation above the ice fall and below the ice fall from the totals and applying this rate to the unsurveyed ice surface. Quantities of ablation were then calculated for the intervening period, when the party was not on the glacier, by means of a series of aerial photographs which showed the seasonal progression of the snow line and associated new areas of ice ablation.

The positions of the transient snow line were sketched on the map from the aerial photographs, and the areas of exposed ice between positions ascertained by planimetry using a Coradi compensating planimeter. These areas were treated separately at first and the amounts of ablation having taken place in each one were later added together. The assumption was made that ice ablation begins as soon as the snow melts and continues until the close of the season at the average ablation rate. When ascertaining ice ablation between any two dated positions of the snow line, the amount below the upper position as the snow line is progressing from the lower one is considered to be one-half of that which would have ablated had all the snow disappeared at one time. Ice ablation was computed by multiplying the area by the average daily ablation rate and by the number of days the area is subjected to ablation. The total volume of ice ablated from all areas was then converted to water volume by multiplying by the density of the ice which is $0 \cdot 85 \mathrm{~g} . / \mathrm{cm}$. ${ }^{3}$. Net snow accumulation was ascertained by multiplying the average depth of snow in the accumulation zone by the area of the zone and by the density of the snow which is $0.55 \mathrm{~g} . / \mathrm{cm} .{ }^{3}$. If the water equivalent volume of snow is larger than that of ice, the budget is positive; if the volume is smaller, it is negative. It is believed that this method, because it takes into account snow line migration, provides a more realistic portrayal of total ablation than one whereby only ablation data from the stake positions are used for the calculation.

The value given for snow density $\left(0.55 \mathrm{~g} . / \mathrm{cm} .{ }^{3}\right)$ is believed sufficiently accurate for use as a constant. Snow measured in pits located in the center of the névé field at $c$. I,200 and c. I, $300 \mathrm{~m}$. had a density of $0.55 \mathrm{~g} . / \mathrm{cm} .{ }^{3}$ on 14 September 1957 . This shows good agreement with Nielsen's conclusion that snow density averages $0.55 \mathrm{~g} . / \mathrm{cm} .{ }^{3}$ over the nearby Taku Glacier accumulation zone (Nielsen, I957). Similarly, Miller (I954) found densities of o.54 and $0.56 \mathrm{~g} . / \mathrm{cm} .{ }^{3}$ during the first and second weeks of September on the Taku Glacier, and LaChapelle (1954) measured an average density of $0.5^{1} \mathrm{~g} . / \mathrm{cm} .{ }^{3}$ for his ${ }^{1} 5$-pit survey of the Juneau Ice Field. The latter study was completed in August and further compaction undoubtedly occurred. LaChapelle states: "One of the first characteristics which becomes apparent upon examination of the profiles is the remarkable uniformity of snow density in vertical profile, in distribution over the ice field, and with time".

In 1957 a party was on the glacier early and late in the ablation season. At the beginning of June, ablation stakes were implanted - one below the ice fall and I 8 adjacent to movement tripods along four cross-glacier profiles above the ice fall. The stake below the ice fall was set in ice and several of those above were placed in ice under a cover of snow. When the 
stakes were set, no ice was exposed above the ice fall and below were only intermittent patches of ice. Not until i 5 June did the snow line begin to retreat up-glacier from the top of the ice fall.

The progression of the seasonal snow line was traced by means of aerial photographs taken on 17 June, 7 July, 9 and 26 August, and 15 and 18 September. The upper glacier on I 5 September appears in Figure 2. When the party returned in September, only I I of the I9 stakes implanted were recovered. The stake below the ice fall had ablated out, and in order to obtain an ablation rate for this part of the glacier, another stake was set in the ice

Table I. Hydrological Budget for Lemon Creek Glacier, i956-57 and 1957-58

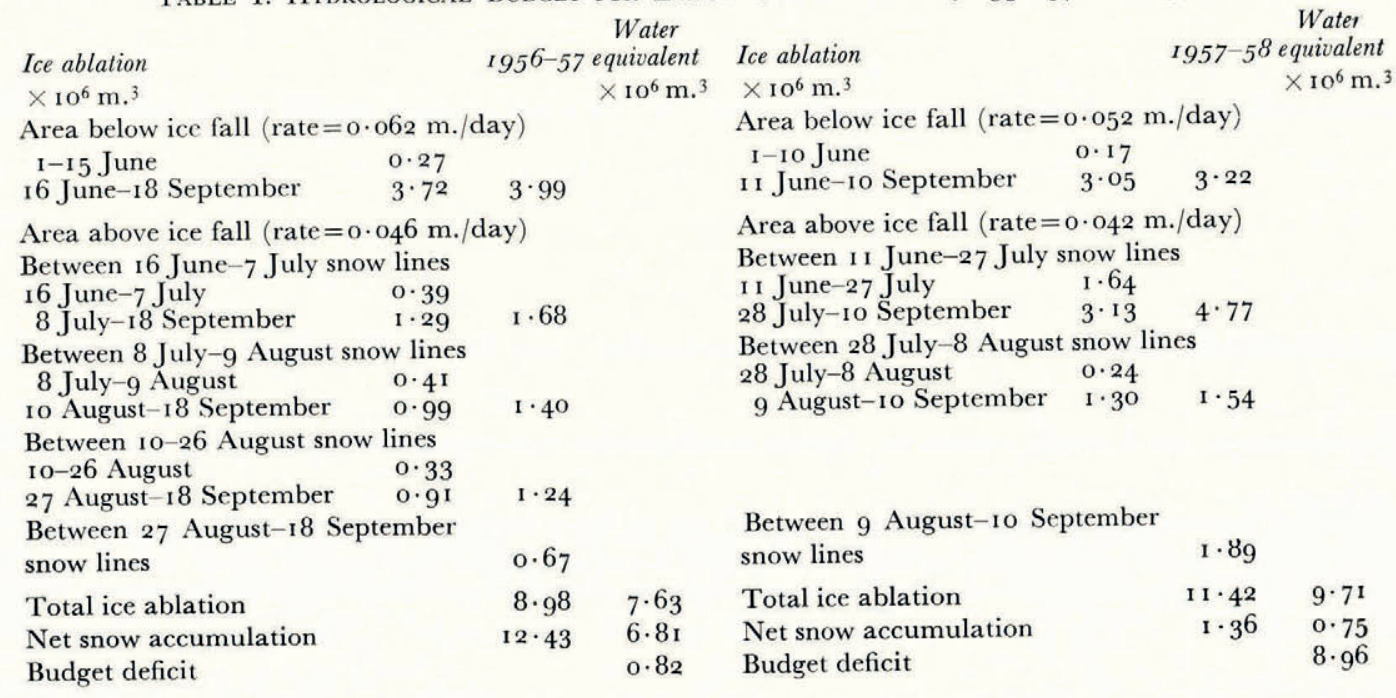

for an II-day period. The rate was found to be $0.057 \mathrm{~m}$./day. Since this rate is presumed to be less than the rate for the entire ablation period, it was compared with rates for the 1954 and 1956 field seasons, and a rate of $0.062 \mathrm{~m}$./day was figured to be that actually in effect. The average ablation rate above the ice fall was $0.046 \mathrm{~m}$. day.

A deficit of at least $0.82 \times 10^{6} \mathrm{~m}^{3}$ occurred during the $195^{6}-57$ budget year. The area of ablation measured $3.68 \times 10^{6} \mathrm{~m}^{2}$ and the area of accumulation, $5.68 \times 10^{6} \mathrm{~m} .^{2}$. Since ablation measurements ended on 8 September, an additional loss of snow presumably occurred until October which is assumed to be the closing date of the ablation period. The budget sheet for $195^{6-57}$ is shown in Table I.

Observations during the $1957-58$ budget year were begun on 25 May before the onset of ice ablation. Nine stakes were implanted at different locations from below the ice fall to the upper part of the glacier. At this time the snow cover was $0.76 \mathrm{~m}$. deep below the ice fall and $2.1 \mathrm{~m}$. deep immediately above it. Five of these stakes were recovered and reset when observations were continued on 25 July. Between 25 and 28 July, 14 additional stakes were set out along three cross-glacier movement profiles. The amount of ablation at each stake was measured on 7 September, and a survey of the snow depth in the accumulation zone was conducted on the following day. The ice ablation rate below the ice fall amounted to $0 \cdot 05^{2}$ $\mathrm{m}$./day; the rate above averaged $0.042 \mathrm{~m}$./day, ranging between 0.039 and $0.048 \mathrm{~m}$./day. The average snow ablation rate was also $0 \cdot 042 \mathrm{~m}$./day, and the average snow depth amounted to $0.4 \mathrm{~m}$. on ro September.

The procedure used for calculating the $195^{6-57}$ budget was followed again during $1957-5^{8}$. It was assumed that changes in the size of the glacier since 1957 were negligible, and the map made in 1957 was again used for planimeter measurements of the ablation and accumulation 
areas. The budget showed a deficit of $8.96 \times \mathrm{I}^{6} \mathrm{~m} \cdot{ }^{3}$, which is considerably more than that for the previous year. The ablation area on 1o September, $5.96 \times 10^{6} \mathrm{~m}^{2}$, was greater and the accumulation area, $3.40 \times 10^{6} \mathrm{~m}^{2}$, less. The ablation period on which figures are based is from I June until ro September. Because the observations were not made later than io September, it is apparent that a much larger deficit resulted before the end of the ablation period on I October. In fact, by 20 September, theoretically, all the $1957-58$ snow cover should have ablated. The ${ }_{1957-58}$ budget sheet appears in Table I.

\section{Budgets $1953-56$}

Prior to 1957 E. R. LaChapelle conducted budget surveys on Lemon Creek Glacier (American Geographical Society, r955, 1956). Because area measurements were made on a map less accurate than the 1957 one, budget figures do not attain the accuracy of the $1956-57$ and ${ }_{1957-58}$ years. Moreover, since budgets have been computed from two different maps, loss or gain volumes before and after 1956 are not absolutely comparable, though their relative orders of magnitude appear to be correct.

1953-54. A surplus of $3.32 \times 10^{6} \mathrm{~m} .{ }^{3}$ of water was ascertained from the 1954 observations which began on 8 June and lasted until ${ }_{4}$ September. This figure was later corrected to a deficit of $3.80 \times \mathrm{IO}^{6} \mathrm{~m} .{ }^{3}$ when the actual amount of snow remaining from the $1953-54$ year was measured in pits dug in the glacier the following field season. Average rate of ice ablation below the ice fall was $0 \cdot 060 \mathrm{~m}$./day. On ${ }_{14}$ September ice was exposed over $c .33$ per cent of the glacier.

1954-55. A large surplus calculated to be $14.78 \times \mathrm{IO}^{6} \mathrm{~m} \cdot{ }^{3}$ on 7 September was later recalculated to be $12.60 \times 10^{6} \mathrm{~m} \cdot{ }^{3}$ when pit stratigraphy was examined in 1956 . Only i I per cent of the glacier had exposed ice on 7 September. At the end of July more than $5 \mathrm{~m}$. of snow covered the accumulation zone; this snow cover measured $5.36 \mathrm{~m}$. in 1956 . The mean ablation rate for snow was $0.050 \mathrm{~m}$./day during the field season which lasted from 12 June until late July.

1955-56. Average ablation rates for the $1953^{-58}$ period were highest during the 1956 ablation season. They were measured from late June till late August. Rates for ice were $0.068 \mathrm{~m}$./day below the ice fall and $0.045 \mathrm{~m}$./day above it. Snow ablation averaged 0.058 m./day. On 21 August a deficit of $4.67 \times 10^{6} \mathrm{~m} .{ }^{3}$ had already occurred, and LaChapelle believed that this volume had at least doubled to $9 \cdot 34 \times 10^{6} \mathrm{~m} .{ }^{3}$ by the time ablation ended. The deduction seems reasonable in that 1957 pit data from $c$. $1,200 \mathrm{~m}$. reveal no snow accumulation for the $1955^{-56}$ budget year and only $45 \mathrm{~cm}$. of firn were measured in a crevasse exposure at $c$. I, $375 \mathrm{~m}$. This shows good agreement with the $1957-58$ accumulation data when a similar deficit quantity of $8.96 \times 10^{6} \mathrm{~m} .{ }^{3}$ was measured. The $1953-54$ budget is also cited in support of LaChapelle's conclusion. On I4 September 1954 the surplus of $7 \cdot 55 \times$ $10^{6} \mathrm{~m} .{ }^{3}$ measured on 22 August had been reduced to $3.32 \times 10^{6} \mathrm{~m} .{ }^{3}$. Additional loss after ${ }_{14}$ September further reduced this surplus and created a deficit of $3 \cdot 80 \times 10^{6} \mathrm{~m}^{3}$.

\section{Budget résumé $1953-58$}

The budget sheet for the period from 1953 through $195^{8}$ is given below in terms of water equivalent volumes:

$\begin{array}{lcc}\text { Budget year } & \begin{array}{c}\text { Surplus } \\ \times 10^{6} \mathrm{~m} \cdot{ }^{3}\end{array} & \begin{array}{c}\text { Deficit } \\ \times 10^{6} \mathrm{~m} .\end{array} \\ \text { 1953-54 } & - & 3 \cdot 80 \\ 1954-55 & 12 \cdot 60 & - \\ 1955-56 & - & 9 \cdot 34 \\ 1956-57 & - & 0 \cdot 82 \\ 1957-58 & - & 8 \cdot 96 \\ \text { Total } & 12 \cdot 60 & 22 \cdot 92 \\ \text { Net deficit } & - & 10 \cdot 32\end{array}$


Because of ablation that continued after observations were concluded, each field season was taken into account for only two of the five annual budgets (the amount of net snow accumulation was measured in pits dug in the upper glacier the following budget year), the deficit of $10.32 \times 10^{6} \mathrm{~m} .{ }^{3}$ should be regarded as being somewhat less than that which has actually resulted.

\section{Surface Movement and Mass Transfer of Ice}

\section{Surface measurement program}

The movement of ice along the transverse profiles of Lemon Creek Glacier was determined for three profiles established in $195^{8}$ and for two profiles re-established from the 1957 field season. The measurement of movement provided ( $\mathrm{I}$ ) a three-dimensional picture of surface flow characteristics in an alpine glacier near equilibrium and permitted, in conjunction with ablation-accumulation studies, (2) the computation of annual deviation from ideal equilibrium flow for the years in question. Although some earlier movement records are available for Lemon Creek Glacier (American Geographical Society, 1955), it was not until 1957 that bulk flow, as well as surface flow, could be determined accurately. This was made possible during the summer of 1956 when transverse cross-sections were plotted by a gravity method (Thiel and others, 1957).

The procedure used for profile measurement in $195^{8}$ was the same as that used in 1957 and is described by Wilson (1959). In essence, simple triangulation was used to determine two orthogonal coordinate systems with the base lines serving as $y$-axes roughly parallel to the longitudinal flow axis of the glacier. The $x$-axes crossed the glacier laterally and $z$-axes were negative downward. By triangulation, the $x, y$, and $z$ coordinates of the position of each movement stake were calculated at the beginning and end of the measurement period. The absolute value of the displacement of each stake was thus found for each of three axis directions.

In $195^{8}$, five movement stakes each were placed along profiles $\mathrm{I}$ and 2 and four on profile 3 . Although the stakes were placed in early July, poor visibility prevented a satisfactory survey until the end of the month. In 1958 summer movement was, therefore, calculated only for short runs of $24,3 \mathrm{I}$ and 22 days on profiles $\mathrm{I}, 2$ and 3 respectively. Fortunately, it was possible to re-survey the two profiles that had been established the previous year. These stakes reappeared in late August and all five stakes on each profile (profiles I A and $2 \mathrm{~A}$ ) were recovered. The survey of profiles $\mathrm{IA}$ and $2 \mathrm{~A}$ in early September thus provided an opportunity to measure flow directly over a period of exactly one year. This was a considerable improvement over the usual method of estimating annual movement on the basis of short-term observations and allowed a more accurate appraisal of scasonal and annual flow characteristics.

The position, vector velocity and vector direction in the horizontal plane of each movement stake are shown on the contour map of Lemon Creek Glacier (Fig. 4). If the map is studied in conjunction with movement data for the five profiles (Table II), several interesting relationships can be seen regarding surface flow characteristics. Important among these are the various interrelationships which seem to exist between flow, surface configuration and the seasonality of observations. At the upper profile, for example, it can be seen that annual movement extrapolated on the basis of a 24-day measurement period greatly exceeds annual movement directly measured over the period of one year. This is particularly evident at the I, IOO to I,200 m. distance from the west edge of the glacier. Stake 4 of profile I and stake 5 of profile IA are located only a few meters apart, yet stake 4 shows an annual horizontal movement increment of $27.6 \mathrm{~m}$. compared to $14.4 \mathrm{~m}$. at stake 5 . At first glance, it would appear that the $195^{8}$ tripod was moving at almost twice the rate of its 1957 neighbor. A check of the annual movement of stake 5 , as extrapolated from an 88-day measurement run in 1957 , shows, however, that the predicted one-year flow also considerably exceeded actual flow as measured one year later. These facts seem to indicate that Lemon Creek Glacier ice 
does indeed subscribe to the theory that maximum flow occurs in the summer months and the rate of movement decreases during the wintertime. One important qualification is necessary. The nature of random measurement error in this situation is such that the possible limits of error regarding the position of individual stakes increased inversely to the length of the measurement period. It follows that the shorter the surveying period involved, the greater is the opportunity to overstate the vector velocities.

Table II. Surface Movement Data for Lemon Creek Glacier

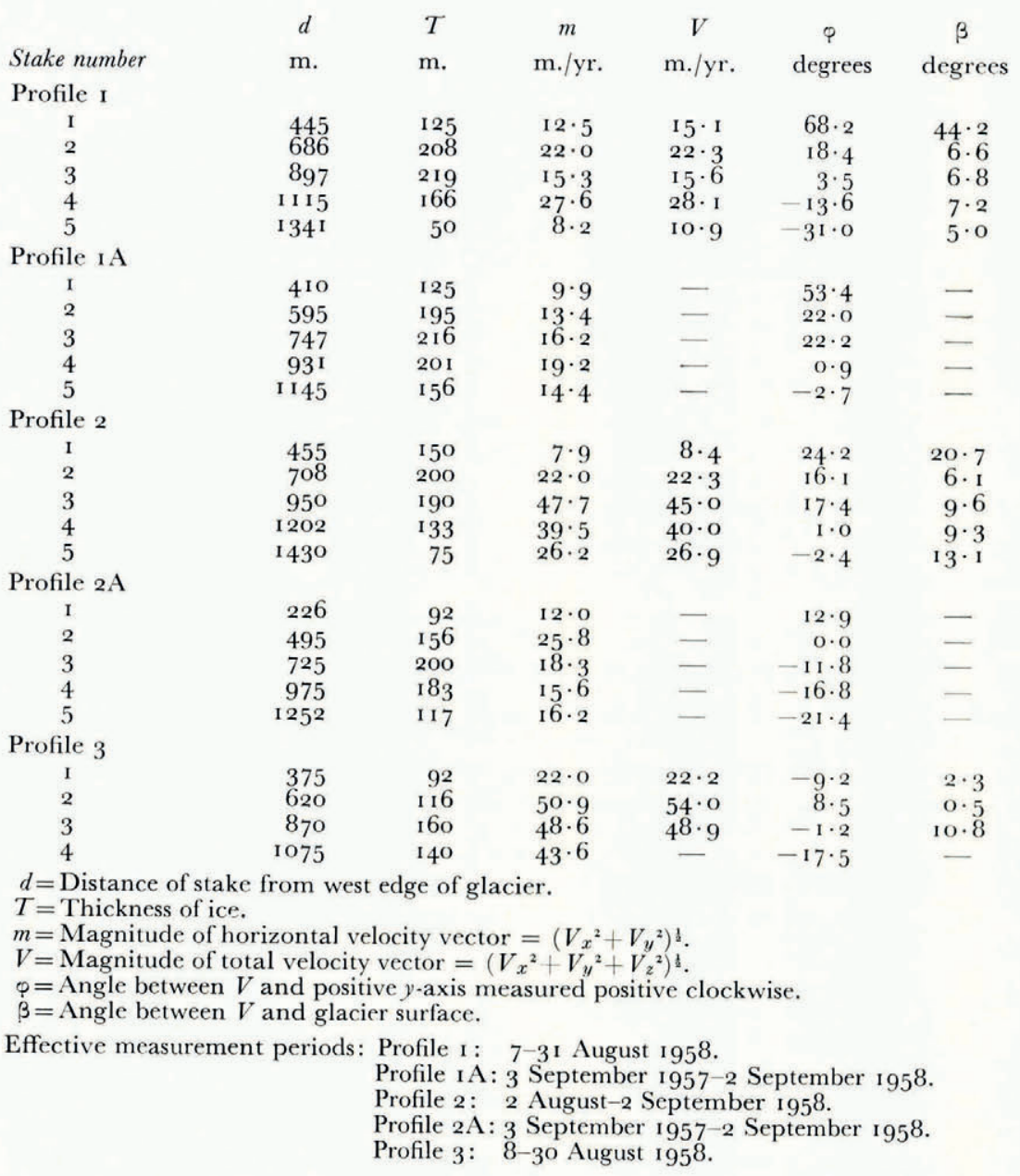

No such inferences can be drawn from the two middle profiles. Due to an error in the arrangement of stakes on profile 2, the 1957 and $195^{8}$ profiles are not contiguous and cannot be accurately compared (Fig. 4). Profile 3 presents a comparatively complex picture. Because of directional changes in the glacier path, the entry of a tributary glacier from the east, and changes in the flow characteristics due to the down-glacier position of the profile, the vector pattern expected does not emerge. For reasons that will be discussed later, stakes I and 2 behave in a predictable pattern; that is, they are tending to move away from the longitudinal axis of the glacier. Stake 3 , however, is retarded in its outward movement by the lateral influence of the incoming tributary ice. It should be noted also that stake 3 has moved positive, 
or upward, along the $z$-axis. Stake 4 is probably affected by its position at the extremity of a turn and by the force of the entering tributary. Stake 2 behaves in a manner that cannot be satisfactorily explained.

\section{Mass transfer of ice}

The regimen and flow of ice in various forms of equilibrium glaciers are mathematically described by Nielsen (1 955). Lemon Creek Glacier, especially above profile 3, closely resembles the idealized glacier type named by Nielsen (Case 2). According to him, "The width is

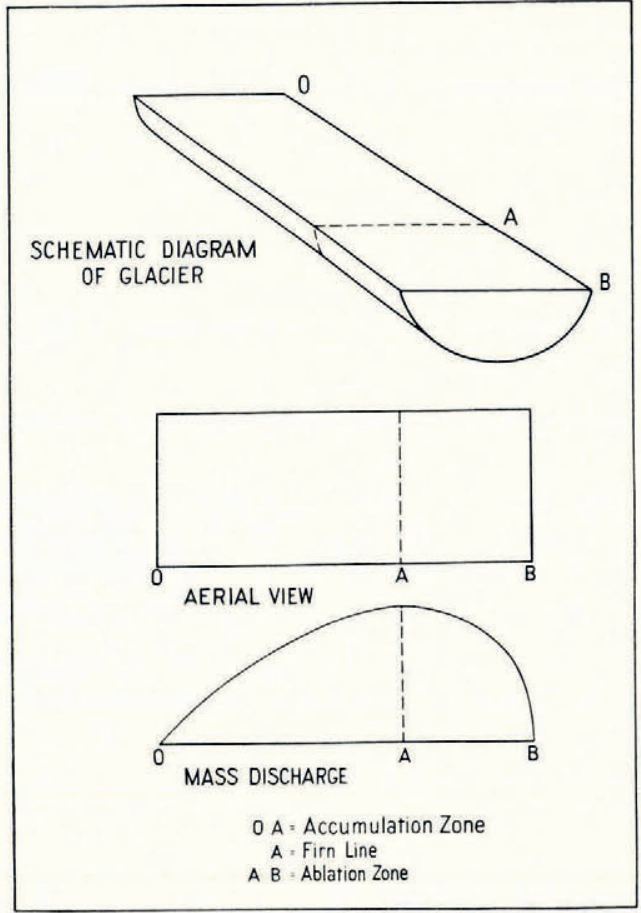

Fig. 5. Schematic diagram, aerial view, and mass discharge of an idealized glacier (after Nielsen (1955))

constant. Rate of accumulation is ... maximum at the head of the glacier and decreases to zero at the firn line. The rate of ablation is zero at the firn line and increases linearly to a maximum . . . at the terminus." Figure 5 defines the form and mass discharge curve of such a glacier. Ideally, ice should "sink", or flow downward, into the interior of the glacier from the surface source zone until, in the vicinity of the firn line, it begins its eventual rise to the surface in the ablation zone. Similarly, ice should converge on the longitudinal axis above the firn limit and diverge from the glacier axis in the ablation zone.

These facts are well illustrated by Wilson's (1959) study of Lemon Creek Glacier's accumulation zone. Actually, it is rather surprising that the movement data and flow theory show such close agreement. Much the same results were obtained in 1958, but the degree of agreement is not as complete as in the previous year. This may be partly attributed to the addition of the complex third profile. Also, the utilization of the precise contour map (a rough outline map of the glacier was used earlier) reveals the need for some adjustments in the 1957 measurement data. 
Table III. Mass Transfer Data for Lemon Creek Glacier, $195^{8}$

\begin{tabular}{|c|c|c|c|c|c|c|}
\hline \multirow[t]{2}{*}{ Profile } & \multirow[t]{2}{*}{$\begin{array}{c}\bar{v}_{i} \\
\mathrm{~m} \cdot / \mathrm{yr} .\end{array}$} & \multirow[t]{2}{*}{$\begin{array}{c}\bar{v} \\
\mathrm{~m} . / \mathrm{yr} .\end{array}$} & \multirow[t]{2}{*}{ 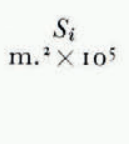 } & \multirow[t]{2}{*}{$\underset{\mathrm{m} \cdot{ }^{2} \times 10^{6}}{A_{i}}$} & \multicolumn{2}{|c|}{$\begin{array}{c}M_{i} \\
\mathrm{~m} \cdot{ }^{3} \times 10^{6 *}\end{array}$} \\
\hline & & & & & $\begin{array}{l}\text { Equation (2) } \\
M_{i}=p \bar{u} S_{i}\end{array}$ & $\begin{array}{c}\text { Equation } \\
\qquad M_{i}=K A_{i}\end{array}$ \\
\hline 1 & 10.2 & $8 \cdot 7$ & $2 \cdot 10$ & $2 \cdot 44$ & I. 55 & 0.53 \\
\hline $1 \mathrm{~A}$ & $7 \cdot 3$ & $6 \cdot 2$ & $2 \cdot 10$ & $2 \cdot 44$ & $I \cdot I I$ & 0.53 \\
\hline 2 & $18 \cdot 6$ & $\mathrm{I}_{5} \cdot 8$ & $2 \cdot 06$ & $4 \cdot 5^{8}$ & $2 \cdot 77$ & $1 \cdot O I$ \\
\hline $2 \mathrm{~A}$ & 13.5 & II 5 & $2 \cdot 04$ & $5 \cdot 18$ & I $\cdot 99$ & $1 \cdot 14$ \\
\hline 3 & $26 \cdot 6$ & $22 \cdot 6$ & $I \cdot 46$ & $7 \cdot 4^{8}$ & $2 \cdot 80$ & $6 \cdot 79^{\dagger}$ \\
\hline & & & $\begin{array}{l}\text { Vater equi } \\
\text { y equation }\end{array}$ & & & \\
\hline
\end{tabular}

The average down-glacier components of surface velocity $\bar{v}_{i}$, for the five profiles are computed by numerical integration and are shown in Table III. As noted earlier, the 1958 profiles indicate greater apparent movement than do the 1957 profiles. Average bulk velocity, $\bar{v}$, across each profile is computed from the equation

$$
\bar{v}=k \bar{v}_{i},
$$

where $k$ is a constant. As should be expected, the average down-glacier components of velocity increase from the upper to the lower profiles. The angles of inclination of the velocity vector do not, however, demonstrate any appreciably greater downward flow at the upper profile (Fig. 4). In 1957, this relationship was quite obvious between profiles I and 2. At profile 3, the ice shows a definite tendency to move toward the surface in the ablation zone.

Convergence of the stakes toward the longitudinal axis is clearly demonstrated for the two profiles in the accumulation zone (Fig. 4). It can also be seen that convergence components along the $x$-axis are greater for profile I than for profile 2. Profile 3 reveals the confusion created by divergence and the presence of a tributary glacier, as discussed earlier.

The mass of ice, $M_{i}$, flowing through a cross-section of known area, $S_{i}$, may be calculated from the equation

$$
M_{i}=p \bar{v} S_{i},
$$

where $\rho$ is the density of ice in the glacier. If the glacier is in equilibrium, $M_{i}$ as computed by equation (2) should be equal to $M_{i}$ as computed by the equation

$$
M_{i}=K A_{i},
$$

where the annual net accumulation per unit $K$ is constant over the Area $A_{i}$. Mass transfer of ice through the profiles has been calculated using these equations and is shown in Table III. Equation (3) shows the mass of ice that should move through the cross-section if the annual flow of ice and the amount of ice replaced by firnification are equivalent. The actual annual flow past each profile is computed by equation (2).

\section{Hydrological Budget and Movement Relationships}

Field studies of the glacier permitted the determination of the hydrological budget as well as some discussion of its deviation from an equilibrium condition. Two approaches were available: (I) the comparison of real and ideal flow as computed from the mass transfer equations, and (2) the computation of annual net budget by direct measurement of total accumulation and ablation in a given year. The results of these two methods were presented earlier. They should, ideally, complement each other and provide parallel means to a single conclusion regarding the character of equilibrium.

Little explanatory discussion need be devoted to the annual budget as determined by direct measurement. Reference to the budget résumé for I $953^{-58}$ shows that the first, third and fifth years were significant deficit years, while 1954-55 showed an impressive surplus. 
The fourth year, although a deficit one, demonstrated the closest approximation to equilibrium. It would be misleading, however, to say that because a surplus or deficit existed in a particular year, that the glacier fluctuated accordingly from true equilibrium. More properly, the total of the five seasons indicates almost twice as much water was lost as gained and, therefore, a general, if not impressive, tendency towards shrinkage exists.

Using mass transfer data, much the same results are obtained. As previously shown for measured budgets, mass movements as determined by equation (3) are also apt to reflect inordinate deviations from the general trend. It is thus desirable to calculate $M_{i}$ using the average value of $K A_{i}$ over a period of years, but because of differences in field measurement methods, it is not quite proper to average accumulation data for periods before and after 1957. Wilson (1959), however, attempts to estimate this figure for the period 1954 to 1957 . For profile IA, he finds that slightly more ice is moving away from the head of the glacier than is formed by firnification.

During the large deficit year of $1957-58$, this relationship was accentuated. Referring only to the profile established in 1957 (and, therefore, the profile indicating the slowest bulk velocity), it is apparent that about twice as much ice passed through profile IA as was replenished. Calculations for $195^{6}-57$ demonstrate roughly the same relationship, although the ratio of replenishment to loss is greater as might be expected for a near-equilibrium year.

For an equilibrium glacier, the average mass of ice ablated should equal the amount of ice passing through a profile located at the average firn limit. The middle profiles on Lemon Creek Glacier correspond to that position. In 1957, profile $2 \mathrm{~A}$ was slightly up-glacier from the snow line. Profiles 2 and $2 \mathrm{~A}$ were, for the most part, down-glacier from the snow line in I 958 . Computing the 1957 ablation from equation (3), we find a loss of $6 \cdot 24 \times 10^{6} \mathrm{~m} .{ }^{3}$ water compared to a measured loss of $7.63 \times 10^{6} \mathrm{~m} \cdot{ }^{3}$ water. Since the net loss in that year was $0.82 \times 10^{6} \mathrm{~m} .{ }^{3}$ water, close agreement is indicated. Similarly, in $195^{8}$, profiles 2 and 2 A lost $\mathrm{I} \cdot \mathrm{OI} \times \mathrm{IO}^{6} \mathrm{~m} .{ }^{3}$ water and $\mathrm{I} \cdot \mathrm{I} 4 \times 10^{6} \mathrm{~m} .{ }^{3}$ water, respectively, according to the equation. Measured ablation in $195^{8}$ was $9 \cdot 7 \mathrm{I} \times 10^{6} \mathrm{~m} .{ }^{3}$ water. The net $195^{8}$ loss of $8 \cdot 96 \times 10^{6} \mathrm{~m} .{ }^{3}$ shows excellent agreement.

For profile 3 , the values of equation (3) may be reversed; that is, the mass of ice flowing through profile 3 should be equivalent to the mass of ice ablated per unit area $K^{\prime}$ constant over the area $A_{i}{ }^{\prime}$ down-glacier from the profile. Thus,

$$
M_{i}{ }^{\prime}=K^{\prime} A_{i}{ }^{\prime} \text {. }
$$

Treating the area below profile 3 in a manner similar to the treatment of the area above profile I, it then becomes evident that approximately 2.4 times as much ice was removed from the glacier below profile 3 than moved through the cross-section to replace it in 1958 . This agrees generally with the results for profile I. Although some error is undoubtedly induced by the curvature of the glacier and the ice fall in the terminus region, the strong deficit trend for 1958 is reaffirmed.

For Nielsen's theory of equilibrium flow to be correct, close agreement is necessary between the measured hydrological budget and the predicted budget as computed from the movement profiles. It is believed that sufficient agreement is demonstrated to verify the theory. The glacier is not, of course, in equilibrium, but it is reasonably close to equilibrium and behaved in every manner predicted by Nielsen for a glacier with a negative regime. This includes not only the changes in net nutrition and attrition, but also the annual fluctuations of the firn limit as a reflection of glacier health.

\section{AcKnowledgements}

Studies included here were carried out under contract with the U.S. Office of Naval Research (Contract N9 onr-830or) with equipment provided by the U.S. Office of the

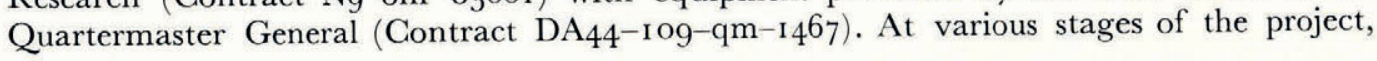


support was given by the Alaskan Air Command, U.S. Coast Guard, Civil Aeronautics Administration, Snow, Ice and Permafrost Research Establishment, U.S. Corps of Engineers, Air National Guard and U.S. Forest Service.

The authors wish to thank the above organizations and their personnel for contributing time, energy and financial aid which enabled the collection of data interpreted in this paper. They deeply appreciate the interest and assistance of their field companions and particularly wish to thank William O. Field, Edward R. LaChapelle, Charles R. Wilson, Anthony Thomas, Kenneth Løken, Richard B. Scott, Davis V. Bohn, David C. Chappelear and Lawrence E. Nielsen.

MS. received 26 October 1962

\section{REFERENCES}

Ahlmann, H. W. 1953. Glacier variations and climatic fluctuations. New York, American Geographical Society. (Bowman Memorial Lectures, Series 3.)

American Geographical Society. 1953-58. Juneau Ice Field Research Project. American Geographical Society. Funeau Ice Field Research Project. Progress and Semi-Annual Status Reports.

American Geographical Society. 1960. Nine glacier maps: northwestern North America. American Geographical Society. Special Publication No. 34, [v, 37] p. plus 9 separate map sheets.

Case, J. B. 1958. Mapping of glaciers in Alaska. Photogrammetric Engineering, Vol. 24, No. 4, p. 8 I $5^{-2}$ I.

Field, W. O., and Miller, M. M. 1950. The Juneau Ice Field Research Project. Geographical Review, Vol. 40,
No. 2, p. 179-90.

Hubley, R. C. 1955. Measurements of diurnal variations in snow albedo on Lemon Creek Glacier, Alaska. fournal of Glaciology, Vol. 2, No. 18 , p. 56o-63.

Hubley, R. C. 1957. An analysis of surface energy during the ablation season on Lemon Creek Glacier, Alaska. Transactions. American Geophysical Union, Vol. 38, No. 1, p. 68-85. LaChapelle, E. R. 1954. Snow studies on the Juneau Ice Field. American Geographical Society. Funeau Ice Field
Research Project. Report No. 9. Miller, M. M. 1954. Juneau Ice Field Research Project, Alaska, I950 summer field season. American Geographical
Society. Funeau Ice Field Research Project. Report No. 7 .

Nielsen, L. E. 1955. Regimen and flow of ice in equilibrium glaciers. Bulletin of the Geological Society of America,
Vol. 66, No. 1, p. I-8. Gielsen, L. E. 1957. Preliminary study on the regimen and movement of the Taku Glacier, Alaska. Bulletin of the
Geological Society of America, Vol. 68, No. 2, p. $171-80$.

Sharp, R. P. I949. Status report of glaciological work on the Seward Ice Field, Yukon Territory. American Alpine
Fournal, Vol. 7, No. 2, p. I 78-83. Tournal, Vol. 7, No. 2, p. I $78-83$.

Thiel, E., and others. I 957. The thickness of Lemon Creek Glacier, Alaska, as determined by gravity measurements, by E. Thiel, E. LaChapelle and J. Behrendt. Transactions. American Geophysical Union, Vol. 38, No. 5, p. 745-49.

Wilson, C. R. 1959. Surface movement and its relationship to the average annual hydrological budget of Lemon Creek Glacier, Alaska. Journal of Glaciology, Vol. 3, No. 25, p. 355-6r. 